\title{
SELF-CHOSEN STUDENT GROUPS - WHAT IS THE STUDENT IMPACT IF ONE IS NOT PART OF HIS/HER IDEAL TEAM?
}

\section{DONALD KUDEK}

\begin{abstract}
:
Colleges and universities have increased student group work in business curriculum since the business community is looking for students able to work in this environment. Although it has been shown to provide students with added teamwork, communication, and problem solving skills, group work creates challenges in grading, social loafing, and motivation. To help reduce these issues, professors have allowed students to pick their own teams, which has created its own set of issues and concerns. Although studies have shown students prefer to choose their own teams, transfer students, student with learning challenges, or just the "odd man out" issue when social circles do not match team sizes, could cause those students to have a negative learning experience. Through a research study of undergraduate business students at Wisconsin Lutheran College, the author hoped to gain a greater understanding of the impact on learning that students face when they are not able to join their ideal team choice when teams are self-selected. Students in Microeconomics (BUS 181) where the professor chooses the teams and two classes where students choose their own teams provided the research subjects. The author utilized an adaptation of a study instrument from Marks and O'Connor (2013), conducted at Longwood University in Farmville, Virginia. Although the author was concerned that students that were able to choose their own teams, but did not become part of their ideal team, would have a negative learning experience compared to other self-selected teams as well as teams assigned by the professor, the data gathered did not support the hypothesis. Convenience sampling and small sample sizes may have contributed to the results, and thus additional research and analysis should be completed on this important topic.
\end{abstract}

\section{Keywords:}

Group Work, Colleges, Universities, evaluation, education impact

JEL Classification: 121

\section{Authors:}

DONALD KUDEK, Wisconsin Lutheran College, USA, Email: donald.kudek@wlc.edu

\section{Citation:}

DONALD KUDEK (2016). Self-Chosen Student Groups - What is the student impact if one is not part of his/her ideal team? . International Journal of Teaching and Education, Vol. IV(2), pp. 63-87., 10.20472/TE.2016.4.2.004 


\section{Introduction}

According to Jones and George (2013), a group is two or more individuals that work together to accomplish a goal or objective. Arrow, McGrath, and Berdahl (2000) state the objectives of small groups include "provide enjoyable activities, to complete projects, to create political solidarity, to make money, or to enhance the status of members" (p. 4). Regardless of the reason for the group, one key criteria remains that the purpose of group formation is that the individuals working together in a group can produce something superior than if the individuals worked independently and then combined the results of their efforts at a later date (Jones \& George, 2013). In addition, when the group is comprised of business students from a college or university as part of a business course, teamwork helps students gain insights from each other, solve issues from multiple perspectives and orientations that only a group of individuals can provide, and provide insights into the real working world of businesses (Jassawalla, Malshe, \& Sashittal, 2008).

As a result of demand from the business community, business programs in many colleges and universities have incorporated group work into their curriculum. This is based on the fact that universities look to replicate business practices of working in group settings (Bosco, Jervis, \& Harvey, 2009). This is further amplified when the team in place is a cross-discipline team since many startup companies benefit from these types of diverse groups (Lüthje \& Prügl, 2006). Although the benefit of having cross discipline teams is known, managing these teams can be more difficult based on personal barriers or stereotypes (Lüthje \& Prügl, 2006). A second reason many colleges and universities are increasing the group activity within the curriculum is due to the fact American Assembly of Collegiate Schools of Business (AACSB) believes that one of the relevant support skills needed by today's university graduates is teamwork (Amato\& Amato, 2005). The AACSB requires colleges and universities to define learning goals that are consistent with the overall mission and vison of the institution and be able to articulate and measure the student outcomes that are a result of the learning goals and activities (Loughry, Ohland, \& Woehr, 2014). As a result, institutions like Minnesota State University, Mankato, require that teamwork be assessed in its Principles of Management course, since the course is required by all business students, and teamwork is a required activity in order for the University to be accredited by the American Assembly of Collegiate Schools of Business.

This need to train students to be proficient in skills required by the business community, and the fact that the American Assembly of Collegiate Schools of Business requires universities and colleges seeking accreditation to prove proficiency in group work activities for students (Amato \& Amato, 2005), a great deal of research has been completed on what is the best method to deliver this educational requirement to students. Which classes should include teamwork in its requirement? Should the teams be selfchosen by the members of the team or should they be selected by the professor? If the teams are selected by the professor, should the team members be chosen at random 
giving the students exposure to multiple individuals and "fairness" between teams or should some other criteria be used to place selected members into specific teams. If criteria is used to assign team members, should personality, leadership capabilities, majors, GPA, and/or gender be considered?

Although each method has its own set of positives and negatives, allowing students to self-select their teams, seems to be the method preferred by students. However, one piece of information missing from the literature deals with the students that are allowed to choose their own team, however do not get to be part of their ideal team for one reason or another. Examples include transfer students that do not know many other students, students that are the "odd person out" when, for example, a group of four friends need to form a team of three for a particular assignment, and the person is told you need to find another team. How does one handle international students that are perceived to hurt the presentation due to less than perfect English skills or the student that is perceived to have some learning or social deficiencies? The look on the faces of this group of students as they wonder around the room looking to find a team tells the agony and concern they feel for team projects.

\section{Literature Review}

\section{Student Group Dynamics}

There is no doubt, a good professor would want every student to have equal opportunity to perform well on the team tasks. One factor that has been shown to impact success is the concept of self-efficacy, or the "belief that one possesses the skills and abilities to successfully accomplish a specific task" (Stone \& Bailey, 2007, p.258). If a student or students are placed on a team with little knowledge or impute as to the partners they must work with, the confidence that one can accomplish the task at the outset may be diminished. Even if the person has great confidence in his or her own ability to accomplish the task, since they will now be working with others that they know very little about, their own self-efficacy could be severely reduced. Without self-efficacy, or at the very least a reduced feeling of self-efficacy, people will not have the same level of drive and persistence to learn, which will have a negative impact on the outcomes of the task (Stone \& Bailey, 2007, p.258). It is critical to give students as much confidence as possible as they begin the project undertaking.

One criteria used to help provide students equal opportunity is to develop teams that have equitable academic qualifications. To do that, the average academic performance of the team should be close to the average academic performance of the class as a whole (Cutshall, Gavirneni, \& Schultz, 2007). If one student team or another has an unfair academic advantage, students may feel they have limited chance of success. Although many criteria are developed to help with group diversity, some group coordinators believe that no team should contain just one female or just one international student. Teams 
without one or both of these classifications are allowed, but teams with student in one or both of these categories, must have a minimum of two females and/or international students (Cutshall, Gavirneni, \& Schultz, 2007). Although the value of international students can be seen with increased diversity and viewpoints, the increased diversity and backgrounds of students increases the challenges of a group's success. Decker, Calo, Yao, and Weer (2014) studied over 800 American and Chinese students that provided evidence that Chinese students have a greater preference for group work (PGW) than their US counterparts based on the cultural backgrounds of individualistic minded countries versus collectivist minded countries and the fact that the association of helping others and the need for association within a group is greater with Chinese students than with their American counterparts. American and Chinese students believe that group work in important, however, Chinese students see group work as an important source of individual rewards (Decker, Calo, Yao, and Weer, 2014, p. 106). Understanding the ramifications to both parties when student teams consist of members from both backgrounds increases the need for proper group management.

Some of the challenges students face when involved in group activities deal with past experiences. Growing up, any group activity students were involved with included predetermined rules of engagement and were highly supervised by adults prior to and during the activity. As a result, students in classroom group activities find themselves with people they did not choose, without a clear set of rules on how to participate, and without adult supervision to intervene when rules are not followed (Jassawalla, Malshe, \& Sashittal, 2008). Students who are not properly equipped to handle group work deal with the situation by dividing the assignment into various activities and working independently on their portion of the assignment, and as a result, do not receive the benefits associated with group work, such as better interaction, enhanced problem solving skills, diverse ideas, and more hands to do the work (Jassawalla, Malshe, and Sashittal, 2008). As a result of this movement away from true team collaboration, conflict and issues tend not to surface until the end of the process when the students look to gather and take their independent effort and put them together into some type of cohesive output (Jassawalla, Malshe, \& Sashittal, 2008). At this point, usually later in the process, students that have been used to adult intervention, are ill-equipped to handle the conflict.

Unfortunately, the student's experiences with work groups has not always worked the way instructors have envisioned. Some of the reasons for this less than desirable result is due to the fact that students experience issues such as lack of focus, inequalities in the assigned tasks, as well as inequalities in the level and quality of work completed (Bosco, Jervis, \& Harvey, 2009). To help understand and address the conflict issues students are facing, Winter, Neal, and Waner (2005) studied 362 junior and senior business and business-related majors to determine how they dealt with conflict in a business team project. In their study, Winter, Neal, and Waner (2005) defined conflict as "two or more people argued the same idea without presenting new information for at least three 
exchanges" (p. 70). The study revealed that $75 \%$ of traditional-age students and $67 \%$ on non-traditional-age students experienced group conflict at least once during the semester, while over $40 \%$ of the students reported conflict at least once per week. The study revealed that students believe that the most popular way to handle conflict was to get more information, however, the students believe the most effective way to manage conflict was to encourage participation from every member. Conflict experienced by students fall into three categories: relationship conflict, task conflict, and process conflict. Relationship conflict deals with the personality issues students' face while trying to complete a task. Task conflict is the conflict that arises when students look to make decisions about the direction of the activity. Lastly, process conflict deals with the means that students chose to accomplish a particular task (Bosco, Jervis, \& Harvey, 2009).

In contrast, Bosco, Jervis, and Harvey (2009) see the most effective way to reduce conflict is to better educate students on effective conflict management techniques completed prior to the start of the team projects. In this manner, students are equipped to deal with one of the various types of conflict when it arises. Two additional recommendations include using class time to complete team activities, since the work that is done in the class can be supervised by the instructor and the skills needed to resolve a team conflicts can be taught by the instructor, and the instructor should set intermediate deadlines for the project to promote harmony and a sense of accomplishment (Bosco, Jervis, and Harvey, 2009, p. 73). The absence of harmony and sense of accomplishment can foster conflict.

One key issue with student team projects is social loafing. Social loafing is the concept that members of a group have a tendency to put less effort in group work than if required to complete a task on their own (Jones \& George, 2013). In addition to identifying those that contribute less than others as social loafers, students also include the behaviors of submitting poor quality work and disruptive behavior as also part of the social loafing problem (Jassawalla, Malshe, \& Sashittal, 2008). In general, students see little incentive to contribute to the assignment unless their contribution will be evaluated or assessed. Social loafing has many causes, but some deal with team composition and the student's belief that all persons working together on a team project will receive the same grade, regardless of how much effort they contribute since the evaluator has no way to know the true extent of an individual's effort and cannot reward or punish accordingly (Jassawalla, Malshe, \& Sashittal, 2008). Other issues cited by students include being placed on teams with members that have different ability levels, different work ethics, giving up control over their grade, scheduling conflicts, and just the lack of enjoyment working with members of a particular group (Marks \& O'Connor, 2013).

Although the results are not able to be validated externally, Pragman, Bowyer, and Flannery (2010), from Minnesota State University, Mankato, conducted a pre and posttest study on 151 students enrolled in a Principles of Management class over a three 
semester timeframe. Each student enrolled in the class was asked to take the survey at the beginning of the semester and again at the end of the semester. Students were asked to use a 7-point Likert scale to respond to 22 questions about the benefits and values of team projects in five categories. Results of the study comparing the answers from the beginning of the semester to the results of the surveys taken at the end of the semester showed a significant increase in student answers in seven of the 22 statements, with three of the seven increases coming from Section One -The value of the team projects. This data showed that as students are more exposed to properly run teams, they realize the value of team activities.

\section{Professor Chosen Student Groups}

Since a major concern of students is the fairness of the grading, or having their own scores negatively affected by some other member of the team, professors at the Kelly School of Business at Indiana University Bloomington (IUB) require students to complete confidential peer-evaluations which are used to lower grades of students not contributing a fair share of the work, reward students that have performed at extraordinary levels, and what conditions have contributed to an unproductive team (Cutshall, Gavirneni, \& Schultz, 2007). This process captures the benefits of using professor selected teams while reducing the concerns of working on a team project with someone that was not chosen or maybe even known prior to the start of the team activity, as well as working with those that do not have the same grade goals and aspirations.

Since student evaluations can play a role in a professor's career, Kidder and BowesSperry (2012) set out to determine if a link existed between the way an instructor designs team projects and the student evaluations they receive. The design of the team project includes such attributes as weight of the grade, the percent of the final grade determined by peer evaluations, the perceived fairness of the evaluation procedures, and the number of hours dedicated to the team project in lieu of class hours or during regularly scheduled class meetings. Controlling for grade expectation in the class, the authors saw a significant correlation between percent of grade, value of peer evaluations, and class time allowed for project work as it related to professor evaluation. This factor makes developing of the class project subject to factors other than those best determined to be effective.

One additional concern for students relative to team projects is the motivation of the instructor for assigning group projects. Although this paper and many others have highlighted the benefits of group projects, some students believe the rationale and motivation for assigning team projects is to cut down of the amount of grading work that needs to be completed by the professor (Marks \& O'Conner, 2013). 


\section{Self-Chosen Student Groups}

Since many conflicts are based on the different personalities and the feeling of being put into a group, and the fact that professor's evaluations are impacted by student reviews, some professors have allowed students the ability to choose their own groups. To test that theory, Bosco, Jervis, and Harvey (2009) studied the differences between student selected and instructor selected teams. The study was conducted with 90 students in a business policy capstone case where the students completed three case analysis. The teams for the first two cases were randomly selected by the instructor, and the third case students selected their own teams. All three hypothesis were supported which showed that the number of conflicts were less, the various type of conflicts were lower in all categories such as time and personality conflicts, knowledge and workload allocation, and the student performance was enhanced. The idea that students preferred choosing their team was seen especially when professors indicated that the teams required a team leader (Marks \& O'Conner, 2013).

\section{Alternatives for choosing Teams}

Group work is a key component at the Kelly School of Business at Indiana University Bloomington (IUB), where 4000 students, including 200 international students from 32 countries, are required to take four core classes prior to being allowed to take advanced courses in any area of specialization (Cutshall, Gavirneni, \& Schultz, 2007). Given the magnitude and importance of these group projects, the program coordinator "is obliged to insure that no person is placed at a disadvantage by his or her team assignment" (p.266).

Given the complexity and importance of dividing a class of 270 students into 45 teams of six, the Kelly School of Business at Indiana University Bloomington (IUB) developed an integer-programming approach that incorporated the requirements outlined by the program coordinator. This systematic process appeared to be successful based on professor comments that indicated more team cohesion; fewer team complaints; more international student involvement; reduced team issues; and an increase in students coming to consulting time as a group versus as an individual (Cutshall, Gavirneni, \& Schultz, 2007).

Trying to develop teams based on various profiles has become more prevalent. Looking to find a solution to team ineffectiveness, Chung and Meneely (2012) using the Creative Problem Solving Profile (CPSP), determined that teams that had more diversified problem solving profiles were better suited to determine a solution to a creative problem, and the team that had the most equal representation of problem solving styles.

Amato and Amato (2005) determined that personality profiles of the student had an impact on the satisfaction of the team learning activity. Using the Myers-Briggs personality profile, the authors categorized teams as compatible or complimentary. The analysis was conducted on students enrolled in a section of Macroeconomics, normally 
taken by students in the earlier stages of their college education as well as two sections of Marketing Strategy, normally taken by students later in the succession of course offerings. Students in Macroeconomics preferred the "comfort of a compatible group" while students in the Marketing Strategy Group, who had been exposed to more group experiences, "preferred to blend the diverse talents available in a complementary group" (p. 41).

O'Neill and Kline (2008) utilized the four major personality traits of extraversion, conscientiousness, emotional stability, and agreeableness, along with an individual's predisposition to be a team player to determine team cohesion. Although a significant relationship between extraversion, conscientiousness, emotional stability and team cohesion were not supported, agreeableness and an individual's predisposition to be a team player were statistically significant. As it related to team performance, only emotional stability and an individual's predisposition to be a team player showed a significant correlation.

\section{Study Rationale}

Wisconsin Lutheran College, a Liberal Arts College in Milwaukee Wisconsin, began in 1973 with 23 full-time and 14 part-time students. The goal in opening the college was to give members of the Wisconsin Evangelical Lutheran Synod (WELS) a place to send their college - aged children for a Lutheran education when they wanted to pursue careers other than a Lutheran pastor or a Lutheran school teacher (Hartig, 1998). In 1985 the college became a four-year institution and was accredited as such in 1987 (Hartig, 2013). Traditional undergraduate enrollment has grown to approximately 1200 and is accredited by the Higher Learning Commission (www.wlc.edu).

The author of this paper is currently an Assistant Professor of Business at Wisconsin Lutheran College. He joined the staff as a full-time, called member of the faculty on July 1, 2011, after teaching for three years in the college's Adult and Graduate Studies (AGS) program. Prior to that the author taught adult evening classes for 15 years at Lakeland College. The author has experience in teaching entry level economics courses as well as courses in marketing, management, and ethics. He has taught special topics classes in the areas of international entrepreneurship, and social media marketing. The author's full-time teaching career followed a twenty-five plus year management career in areas of marketing, international business, and banking.

As a result of the author's management career, the ever increasing use of team projects in the business world, and the continual need for individuals to work with others during their course of normal activity, the author holds a strong belief that students need to be proficient in team activities. As a result, nearly every class he has taught at the undergraduate level (other than adult learners in the evening due to scheduling issues) has had a group project as part of the required class activity. The class teams were 
initially assigned by the professor under the belief that members that are chosen to work on projects in the business world normally do not get to choose their team members. Realizing some of the issues and conflicts that method presented, especially in freshman and sophomore students, the author reversed his processes to begin to allow students to choose their own teams. This was done to eliminate the issues and problems teams were having with social loafing or personnel issues, since the response could always be, "you picked the team".

Two events this past semester has caused a rethinking of this issue. The first was the materials the author became exposed to as a result of his PhD studies at Regent University, in particular LPHD 764 - Group Behavior. Through various scholarly articles, books, and project work, the author began to gain a greater understanding of group dynamics, and the complexity of them. At the same time, while teaching his normal Marketing Principles class (BUS 240), an event happened that caused him to rethink this process. A student with high functioning Autism/ASD transferred to WLC and enrolled in the class. His disease greatly affects his social skills and as a result comes across as immature and not very intelligent (although his grades would refute that position). As the class members were given time during one class period to locate students with similar project ideas and form teams of three students, the author witnessed this student walking around somewhat lost as he approached a number of teams only to find out that they were full. This concern was somewhat re-emphasized as other transfer students, both domestic and international, did not appear to be comfortable in finding a group since they had only been on campus a few weeks. This was in contrast to the majority of the students that seem to know many other students from previous semesters or sport teams. The combination of these two events has caused the author to rethink the strategy.

One factor that has been shown to impact success is the concept of self-efficacy, or the "belief that one possesses the skills and abilities to successfully accomplish a specific task" (Stone \& Bailey, 2007, p.258). As the author watched the various teams being formed, both those readily being accepted into a group of well-chosen team-mates, as well as the remaining students being forced into team situations where they did not know the other members, it appeared these students began the project at a disadvantage. If all students are placed onto teams, self-efficacy may not be affected since all students are currently in the same situation. However, if students are placed on team with individuals that they do not know or with others that they do not believe will be beneficial to the team's success, while the majority of the teams are being formed with students that each team member wants to work with, self-efficacy may be negatively impacted. As a result, the members of these few "left-over" teams may lack the self-efficacy needed to be successful.

Since the research has shown that students prefer to choose their own teams, the author posits the following hypothesis: 
H1 - Students who can choose their own team will have a more positive group experience that students who did not get to choose their own team.

Students who are allowed to choose their teams, but do not end up being a member of the team they ideally would like, are less likely to be satisfied with the learning experience than those that chose their teams and were able to get onto the team of their choice.

Since students that are in classes where they are allowed to pick their own teams, but do not end up being a member of the team they would like, the author believes their selfefficacy is negatively affected to the point that they believe their grade will be negatively impacted. As a result, the author posits the hypothesis:

H2 - Students who are allowed to choose their teams, but do not get their preferred ideal team, will have a more negative group experience than students who did get their preferred ideal team.

Although students prefer to choose their own teams since they have concern about the professor's motivation for choosing teams the way they do (Kidder \& Bowes-Sperry, 2012), the author posits that when a student is able to choose their own team members, but are not able to join the team of their choice, the students that were just placed on a team will have a better experience than those that could choose their own team, but were not able to join the team of choice. As a result of this, the author states the following:

H3 - Students who have their team assigned to them, will have a more positive group experience than students who could choose their teams, but do not end up being a member of the team they ideally would like.

\section{Method / Procedure Section}

Since the author of the paper is an Assistant Professor of Business at Wisconsin Lutheran College, the author chose to use students within the business college as study samples. In order to conduct research on campus with human subjects, the research must be approved by the college's Institutional Review Board. According to the college's IRB brochure, "The IRB's primary mission is to protect the rights, welfare, and privacy of all individuals participating in research sponsored by Wisconsin Lutheran College". Given the timing of committee meetings and the timing requirements of this research, the author met with Dr. David Brightsman, Dean of the College of Professional Studies and IRB Chair, to discuss the project and receive the required permission to conduct the research in various business classes. Dr. Brightsman approved the request due to the fact that the research was being conducted for a class requirement of the author and was not intended to be published. In addition, the author as a requirement of the class for which the survey is being conducted, completed Regent University's Human Subject Approval form and presented it to Dr. Winner, Class Professor. 
Once the permission was granted, the author met with Professor Greg Pfarr, Assistant Professor of Business at WLC who teaches the entry level Microeconomics course (BUS 181). All students wishing to enter the College of Business at WLC are required to take BUS 181 along with BUS 182 - Macroeconomics. Professor Pfarr requires a group project each semester and for various reasons assigns students into teams rather than letting the students pick their own teams. Other than issues that have been brought to his attention by students or other administrators, Professor Pfarr assigns the teams randomly. As mentioned above, this method has been shown in the past to be the least preferred method by students. Using students from this class was done for a number of reasons. First, BUS 181 contains the largest number of business students in one class taught across multiple sections. Students looking to get accepted into the business program at WLC must average a 2.5 GPA in BUS 181 and BUS 182. This grade pressure is ideal for the study since students need to care about the grade they receive since it may impact their ability to obtain a business degree at WLC. Lastly, this class is one of the first college experiences with group work for many of the class participants. As to avoid any issues with perceived pressure to participate, the study was administered by a student not involved in the class. A paper and pencil test was administered and collected by the student worker and returned to the author in a sealed envelope for analysis. Professor Pfarr was not present in the room while the study was being conducted. Students were informed that the survey is optional and is not part of the required class work. Students were also told that Professor Pfarr was not leading the study.

The second group studied was from two of the author's classes. One class, BUS $240-$ Marketing Principles, is the class discussed above that lead to the idea for this research. Students taking this class normally are freshman and sophomores. Although not required, the majority of the students in this class have taken BUS 181 - Microeconomics in a concurrent or prior semester, thus giving students the experience of a professor chosen team as well as a self-chosen team. Since group work is a common activity at WLC in not only business classes but in many other areas, the author believed the greatest majority of the students participating in the survey have experienced both professor assigned team projects as well as self-chosen team projects and was validated through a survey question. A second class used to conduct the research was BUS $301-$ Business Ethics, a required course for all Business Majors at WLC. Due to the popularity of the class, almost all students in this class are seniors, since it normally fills up prior to the lower classes being able to register. During the Fall, 2015 semester, 59 students were enrolled in BUS 240 and BUS 301, while 62 were enrolled in both sections the BUS 181 Microeconomics. In both BUS 240 and BUS 301, student team projects are required, but students are able to choose which team they wish to join. To insure no pressure is felt to participate, or any influence is felt to answer questions a particular way, a student worker was used to administer and collect the survey in BUS 310 and the completed surveys were returned to the author in a sealed envelope. In BUS 240, students were assembled 
in the hall prior to meeting with the professor and were asked if they would take time to complete the survey and return it to an envelope. Students were not required to take the survey and were not told who was conducting the research prior to completing the survey.

On additional class was used on campus to conduct a test run of the sample instrument. Students in BUS 352 - Organizational Behavior were asked to take a trial run of the test to determine if any questions contained errors or were confusing. The results of that class were not part of the official study. Two clarification issues were pointed out and as a result the instrument was enhanced. At the time of the study, the class was currently studying the concept of teams, which allowed the author to further educate the students with the literature that has been reviewed as part of this project.

Convenience Sampling, also known as "haphazard sampling" is used in research since the subjects to be used in the research are easily available (Cozy \& Bates, 2012, p. 147). Given the fact that the author of the study teaches at the same college as the students participating in the project, some biases may have been introduced, and the results not a complete representation of the population in general, but the use of student workers, along with the anonymous nature of the researcher should have minimized the biases.

\section{Survey Instrument}

In 2009, Marks and O'Connor (2013) completed an extensive survey of the attitudes about group work with the students at Longwood University in Farmville, Virginia. As part of the study, Marks and O'Connor created and distributed an instrument looking to understand the student's attitudes and perceptions about college group work. The survey was completed by 153 business students and 258 students in a 400 level required English class. The instrument consisted of 75 questions covering areas of demographics, group perspectives, and experiences.

The author of this study contacted the Dr. Melonie Marks via e-mail to obtain permission to use the questionnaire in his proposed study. Dr. Marks responded via e-mail with a written approval as long as the original study was quoted within the paper and a note was made that the use of the study was being done with permission of the original authors. Since original study was more comprehensive than the proposed study, the questions were pared down to a total of 26 questions. Although the original survey included a question to determine if the student was a business or non-business major, the question was modified to reflect the various majors of students likely enrolled in the WLC classes being surveyed. In addition, to address the issue outlined in the various hypothesis, a question was added to determine how the student teams were formed, either student chosen or professor assigned. 


\section{Analysis Results}

Once the surveys were completed, the data was stored and analyzed with the help of IBM SPSS Statistics, Version 22 (SPSS). According to the analysis, 99 students completed the survey. This was $81.8 \%$ of students enrolled in the four surveyed classes. However, it is unknown what percentage of enrolled students were in attendance the day the survey was administered. In addition, one of the student workers administering the survey in the BUS 181 - Microeconomics class reported that at least one student stated that they did not take the survey since they had taken it in a previous class. Of the 99 student participants, 71 were male $(71.7 \%)$ and 28 were female $(28.3 \%)$. Student responses indicated that $97 \%$ had been on a professor assigned team in the past and $82.8 \%$ of the respondents indicated they had been on a student team in the past where they were able to choose their own team members. The breakdown of students by major and year in school were (table $1 \&$ table 2 ):

\begin{tabular}{|c|c|c|c|}
\hline Major & \multicolumn{2}{|c|}{ Frequency } & \multirow{2}{*}{$\begin{array}{l}\text { Cumulative } \\
\text { Percent } \\
67.7\end{array}$} \\
\hline Business & 67 & 67.7 & \\
\hline Communications & 6 & 6.1 & 73.7 \\
\hline Communication Arts (CAR) & 11 & 11.1 & 84.8 \\
\hline Other & 10 & 10.1 & 94.9 \\
\hline Undecided & 5 & 5.1 & 100.0 \\
\hline Total & 99 & 100.0 & 100.0 \\
\hline
\end{tabular}

Table 1

$\begin{array}{llll}\text { Year in School } & \text { Frequency } & \text { Percent } & \begin{array}{l}\text { Cumulative } \\ \text { Percent }\end{array} \\ \text { Freshman } & 44 & 44.4 & 44.4 \\ \text { Sophomore } & 19 & 19.2 & 63.6 \\ \text { Junior } & 20 & 20.2 & 83.8 \\ \text { Senior } & 16 & 16.2 & 100.0 \\ \text { Total } & 99 & 100.0 & 100.0\end{array}$

Table 2

Using a Likert scale of 1-5 (1=strongly agree; $2=$ mildly agree; $3=$ neutral; 4=mildly disagree; and $5=$ strongly agree) students were asked general questions in regard to group work activities. To validate the Bosco, Jervis, and Harvey (2009) study that concluded students chosen teams led to enhanced student experience, a number of general questions were asked of students in regard to group activity in general. When 
asked if they preferred to choose their own team, only $11.1 \%$ of respondents stated they mildly or strongly disagreed (table 3).

$\begin{array}{llll} & \text { Frequency } & \text { Percent } & \begin{array}{l}\text { Cumulative } \\ \text { Percent }\end{array} \\ \text { Strongly Agree } & 41 & 41.4 & 41.4 \\ \text { Mildly Agree } & 26 & 26.3 & 67.7 \\ \text { Neutral } & 21 & 21.2 & 88.9 \\ \text { Mildly Disagree } & 9 & 9.1 & 98.0 \\ \text { Strong Disagree } & 2 & 2.0 & 100.0 \\ \text { Total } & 99 & 100.0 & \end{array}$

\section{Table 3}

Cutshall, Gavirneni, and Schultz (2007) advocated for the use of peer evaluations in determining the grade of students to help reduce the student concern of social loafing. Students believe that all persons working together on a team project will receive the same grade, regardless of how much effort they contribute since the evaluator has no way to know the true extent of an individual's effort and cannot reward or punish accordingly (Jassawalla, Malshe, \& Sashittal, 2008). The study confirmed students support the idea of peer evaluations with only $12.1 \%$ of students disagreeing with the statement, "Peer reviews should be done on team members" (table 4) and only $13.1 \%$ disagreeing with the statement that "Peer reviews should be used to determine the grade" (table 5).

$\begin{array}{llll} & \text { Frequency } & \text { Percent } & \begin{array}{l}\text { Cumulative } \\ \text { Percent }\end{array} \\ \text { Strongly Agree } & 21 & 21.2 & 21.2 \\ \text { Mildly Agree } & 30 & 30.3 & 51.5 \\ \text { Neutral } & 36 & 36.4 & 87.9 \\ \text { Mildly Disagree } & 9 & 9.1 & 97.0 \\ \text { Strong Disagree } & 3 & 3.0 & 100.0 \\ \text { Total } & 99 & 100.0 & \end{array}$

\section{Table 4}




$\begin{array}{llll} & \text { Frequency } & \text { Percent } & \begin{array}{l}\text { Cumulative } \\ \text { Percent }\end{array} \\ \text { Strongly Agree } & 23 & 23.2 & 23.2 \\ \text { Mildly Agree } & 41 & 41.4 & 64.6 \\ \text { Neutral } & 22 & 22.2 & 86.9 \\ \text { Mildly Disagree } & 9 & 9.1 & 96.0 \\ \text { Strong Disagree } & 4 & 4.0 & 100.0 \\ \text { Total } & 99 & 100.0 & \end{array}$

\section{Table 5}

The value of peer reviews can also be seen in the fact that only $11.1 \%$ of students stated that they mildly disagreed with the statement "I trust the peer review my teammates give me", with no one indicating they strongly disagreed with that statement (table 6).

$\begin{array}{llll} & \text { Frequency } & \text { Percent } & \begin{array}{l}\text { Cumulative } \\ \text { Percent }\end{array} \\ \text { Strongly Agree } & 30 & 30.3 & 30.3 \\ \text { Mildly Agree } & 43 & 43.4 & 73.7 \\ \text { Neutral } & 15 & 15.2 & 88.9 \\ \text { Mildly Disagree } & 11 & 11.1 & 100.0 \\ \text { Total } & 99 & 100.0 & \end{array}$

\section{Table 6}

Group projects have increased within college business curriculums since universities look to replicate business practices of working in group settings (Bosco, Jervis, \& Harvey, 2009) and the American Assembly of Collegiate Schools of Business (AACSB) believes that one of the relevant support skills needed by today's university graduates is teamwork (Amato\& Amato, 2005). Students surveyed appear to support this trend since $93.9 \%$ of students strongly agreed or mildly agreed with the statement "Learning to work in a group is important" (table 7). 


$\begin{array}{llll} & \text { Frequency } & \text { Percent } & \begin{array}{l}\text { Cumulative } \\ \text { Percent }\end{array} \\ \text { Strongly Agree } & 58 & 58.6 & 58.6 \\ \text { Mildly Agree } & 35 & 35.4 & 93.9 \\ \text { Neutral } & 5 & 5.1 & 99.0 \\ \text { Mildly Disagree } & 1 & 1.0 & 100.0 \\ \text { Total } & 99 & 100.0 & \end{array}$

\section{Table 7}

In addition, $90.9 \%$ of students strongly agreed or mildly agreed with the statement, "My group work has been effective" (table 8).

$\begin{array}{llll} & \text { Frequency } & \text { Percent } & \begin{array}{l}\text { Cumulative } \\ \text { Percent }\end{array} \\ \text { Strongly Agree } & 39 & 39.4 & 39.4 \\ \text { Mildly Agree } & 51 & 51.5 & 90.9 \\ \text { Neutral } & 7 & 7.1 & 98.0 \\ \text { Mildly Disagree } & 2 & 2.0 & 100.0 \\ \text { Total } & 99 & 100.0 & \end{array}$

\section{Table 8}

In addition, $45.5 \%$ of students strongly agreed or mildly agreed with the statement "I learn better in a group versus working alone, with an additional $31.3 \%$ neutral on the statement, leaving less than a quarter of the students to disagree with the statement (table 9).

$\begin{array}{llll} & \text { Frequency } & \text { Percent } & \text { Cumulative } \\ \text { Strongly Agree } & 17 & 17.2 & 17.2 \\ \text { Mildly Agree } & 28 & 28.3 & 45.5 \\ \text { Neutral } & 31 & 31.3 & 76.8 \\ \text { Mildly Disagree } & 16 & 16.2 & 92.9 \\ \text { Strong Disagree } & 7 & 7.1 & 100.0 \\ \text { Total } & 99 & 100.0 & \end{array}$

\section{Table 9}


Lastly, when asked if "Group work has been a positive experience", only $4 \%$ of the students indicated that it had not (table 10).

$\begin{array}{llll} & \text { Frequency } & \text { Percent } & \begin{array}{l}\text { Cumulative } \\ \text { Percent }\end{array} \\ \text { Strongly Agree } & 28 & 28.3 & 28.3 \\ \text { Mildly Agree } & 44 & 44.4 & 72.7 \\ \text { Neutral } & 23 & 23.2 & 96.0 \\ \text { Mildly Disagree } & 2 & 2.0 & 98.0 \\ \text { Strong Disagree } & 2 & 2.0 & 100.0 \\ \text { Total } & 99 & 100.0 & \end{array}$

\section{Table 10}

The software was also used to determine the satisfaction level of the students regarding the group work project, and if students believe their grades have been impacted by not being able to be in the group they ideally would have liked to join based on how the teams were chosen. The data was analyzed relative to the students to determine if the students not in their ideal team are more or less satisfied than those that have no choice in their teammates at all. Based on the author's teaching experience and the studies that have shown students prefer to choose their own teams. Bosco, Jervis, and Harvey (2009) studied both student selected and instructor selected teams and concluded the number of conflicts were less, the various type of conflicts were lower in all categories such as time and personality conflicts, knowledge and workload allocation, and the student performance was enhanced.

However, in the research conducted, the 45 students that were assigned a team had a mean score of 4.18 when asked the question, "I believe my learning experience in this class was negatively impacted by the group I worked with." This would indicate the average score is between mildly disagree and strongly disagree. However, the average score of the 54 students getting to choose their own teams was 3.94 indicating a score between neutral and mildly disagree. In other words, students that were able to choose their own teammates were not as concerned that the class project had a negative impact on their learning experience.

This idea can be reinforced by the answers students gave to the question, "I believe my grade on the group assignment will be/or has been negatively impacted by the group I worked with". Students being part of assigned teams averaged a 4.00 score, indicating a mildly disagreement with the statement, however the students that chose their own teammates averaged a score of 3.81 or slightly more agreement with the statement (table 11). 


\begin{tabular}{|c|c|c|c|}
\hline \multicolumn{2}{|c|}{$\begin{array}{l}\text { How were the current team members } \\
\text { chosen? }\end{array}$} & $\begin{array}{l}\text { My learning is } \\
\text { negatively impacted } \\
\text { by my group work }\end{array}$ & $\begin{array}{l}\text { My grade is } \\
\text { negatively impacted } \\
\text { by my group work }\end{array}$ \\
\hline \multirow[t]{3}{*}{ Professor Assigned } & Mean & 4.18 & 4.00 \\
\hline & $\mathrm{N}$ & 45 & 45 \\
\hline & Std. Deviation & .777 & 1.128 \\
\hline \multirow{3}{*}{$\begin{array}{l}\text { Student Chose } \\
\text { First Choice }\end{array}$} & Mean & 3.96 & 3.80 \\
\hline & $\mathrm{N}$ & 45 & 45 \\
\hline & Std. Deviation & 1.086 & 1.254 \\
\hline \multirow{3}{*}{$\begin{array}{l}\text { Student Chose } \\
\text { NOT First Choice }\end{array}$} & Mean & 3.80 & 4.00 \\
\hline & $\mathrm{N}$ & 5 & 5 \\
\hline & Std. Deviation & .837 & 1.732 \\
\hline \multirow{3}{*}{$\begin{array}{l}\text { Student Not Chose - } \\
\text { Just happened }\end{array}$} & Mean & 4.00 & 3.75 \\
\hline & $\mathrm{N}$ & 4 & 4 \\
\hline & Std. Deviation & .000 & .500 \\
\hline \multirow[t]{3}{*}{ Total } & Mean & 4.05 & 3.90 \\
\hline & $\mathrm{N}$ & 99 & 99 \\
\hline & Std. Deviation & .919 & 1.191 \\
\hline
\end{tabular}

\section{Table 11}

As a result, $\mathrm{H} 1$ - Students who can choose their own team will have a more positive group experience that students who did not get to choose their own team cannot be supported with the data.

Secondly, students that are in classes where they are allowed to pick their own teams, but do not end up being a member of the team they would like, the author believes their self-efficacy is negatively affected and will not be as satisfied with the experience as a student who was able to choose their own team members and was able to join an ideal team. However, the data collected from the 54 students that were able to choose their own teams did not support $\mathrm{H} 2$ which stated - Students who are allowed to choose their teams, but do not get their preferred ideal team, will have a more negative group experience than students who did get their preferred ideal team. Of the 54 students, 45 respondents were able to be part of their ideal team. When asked "I believe my learning experience in this class was negatively impacted by the group I worked with" the average 
score for the students that were part of their ideal team was 3.96 or just shy of mildly disagree. Of the nine students that did not get to be part of their ideal team, their response was 3.89 , showing slightly less disagreement than their counterparts. In contrast, students that were part of their ideal team felt their grade was more negatively affected than those not part of their ideal team, but only slightly with a mean difference of .09.

As mentioned above, research has shown that students prefer to choose their own teams. However, the author posits that when a student is able to choose their own team members, but are not able to join the team of their choice, the negative impact of this scenario is such that the students that were assigned a team by the professor will have a better experience. Similar to the other two hypothesis, the data did not support H3 Students who have their team assigned to them, will have a more positive group experience than students who could choose their teams, but do not end up being a member of the team they ideally would like. When asked the question "I believe my learning experience in this class was negatively impacted by the group I worked with", the average score of students choosing teams but not getting on their ideal team was 3.89 versus 4.18 for the students assigned by the professor. This was also true as it relates to the student's grades when asked "I believe my grade on the group assignment will be/or has been negatively impacted by the group I worked with". Students assigned a team responded with 4.00 while students choosing a team but not part of their ideal team was 3.89 , indicating less disagreement with the statement. As a result of the data, none of the three hypothesis list above could be supported.

This lack of evidence can also be seen in a one-way ANOVA F test. As seen in the Test of Between-Subjects Effects Report, the test is not significant since the $p$ value (located in the column labeled Sig.) is not less than .05 (table 12 and 13). As a result, the null hypothesis is rejected since there is no difference in population means among the groups.

Test of Between-Subjects Effects

Dependent Variable: My learning is negatively impacted by my group work

\begin{tabular}{|c|c|c|c|c|c|c|}
\hline Source & $\begin{array}{l}\text { Type III } \\
\text { Sum of } \\
\text { Squares }\end{array}$ & $d f$ & $\begin{array}{l}\text { Mean } \\
\text { Square }\end{array}$ & $F$ & Sig. & $\begin{array}{l}\text { Partial Eta } \\
\text { Squared }\end{array}$ \\
\hline $\begin{array}{l}\text { Corrected } \\
\text { Model }\end{array}$ & $1.459 a$ & 3 & .486 & .568 & .637 & .018 \\
\hline Intercept & 513.447 & 1 & 513.447 & 600.051 & .000 & .863 \\
\hline $\begin{array}{l}\text { Current } \\
\text { Team }\end{array}$ & 1.459 & 3 & .486 & .568 & .637 & .018 \\
\hline $\begin{array}{l}\text { Error } \\
\text { Total }\end{array}$ & $\begin{array}{l}81.289 \\
1707.000\end{array}$ & $\begin{array}{l}95 \\
99\end{array}$ & .856 & & & \\
\hline $\begin{array}{l}\text { Corrected } \\
\text { Total }\end{array}$ & 82.747 & 98 & & & & \\
\hline
\end{tabular}


a. R Squared $=.018$ (Adjusted R Squared $=-.013)$

\section{Table 12}

Tests of Between-Subjects Effects

Dependent Variable: My learning is negatively impacted by my group work

$\begin{array}{lllllll}\text { Source } & \begin{array}{l}\text { Type III } \\ \text { Sum of } \\ \text { Squares }\end{array} & \text { df } & \begin{array}{l}\text { Mean } \\ \text { Square }\end{array} & \text { F } & \text { Sig. } & \begin{array}{l}\text { Partial Eta } \\ \text { Squared }\end{array} \\ \text { Corrected } & \begin{array}{l}1.040^{\mathrm{a}} \\ \text { Model }\end{array} & 3 & .347 & .239 & .869 & .007 \\ \text { Intercept } & 489.039 & 1 & 489.039 & 336.779 & .000 & .780 \\ \text { Current } & 1.040 & 3 & .347 & .239 & .869 & .007 \\ \text { Team } & 137.950 & 95 & 1.452 & & & \\ \text { Error } & 1644.000 & 99 & & & & \\ \text { Total } & \text { Corrected } & 138.990 & 98 & & & \\ \text { Total } \\ \text { a. R Squared }=.018 \text { (Adjusted R Squared =-.013) }\end{array}$

\section{Table 13}

\section{Discussion}

Research indicates that students like to choose their own teams. However as the author watched students that were able to choose their own teams, but not get to be part of the team they ideally would like, the question arose if the learning experience for those students would be worse than if they had just been assigned a team. Although the looks on their faces would have supported that notion, the data gathered in four business classes at Wisconsin Lutheran College did not support that. Some potential rational for the results are as follows:

1. As seen below, nearly $76 \%$ of the students that were assigned to their teams were freshman (table 14). This might indicate that some of these students had never been part of a college group project where they were able to choose their own teams, thus they were satisfied with the results of the group project. 


$\begin{array}{lllll}\begin{array}{l}\text { Year in } \\ \text { School }\end{array} & \begin{array}{l}\text { Freque } \\ \text { ncy }\end{array} & \begin{array}{l}\text { Perce } \\ \text { nt }\end{array} & \begin{array}{l}\text { Cumulative } \\ \text { Percent }\end{array} & \begin{array}{l}\text { Cumul } \\ \text { ative } \\ \text { Percen } \\ \mathrm{t}\end{array} \\ \begin{array}{l}\text { Freshma } \\ \mathrm{n}\end{array} & 34 & 75.6 & 75.6 & \\ \begin{array}{l}\text { Sophomo } \\ \text { re }\end{array} & 6 & 13.3 & 88.9 & \\ \text { Junior } & 3 & 6.7 & 95.6 & \\ \text { Senior } & 2 & 4.4 & 100.0 & \\ \text { Total } & 45 & 100.0 & & \end{array}$

Table 14

2. Amato and Amato (2005) determined that students in classes taken early in their college career preferred the "comfort of a compatible group" while students in a class taken later in the college rotation and had been exposed to more group experiences, "preferred to blend the diverse talents available in a complementary group" (p. 41). This may have been the case with students in BUS 240 - Marketing Principles. Given the fact that the majority of the students are early in their college careers, they may have chosen teams based on friendships, compatibilities, etc. however when they needed to accomplish a task, they were less satisfied than those that were assigned a team. Friends, teammates, roommates, etc. may make the managing of a project more difficult since other strings are attached than just a college project. If a member of the team that is also a friend or teammate is not contributing as expected, talking to that individual about the issue may be more difficult based on other relationships between the two individuals. As a result, the level of satisfaction may be diminished and become visible in a confidential survey. This idea may also hold true for those that did not get to be part of their ideal group. Since they ended up together "by default" they were in essence bound by one activity, the class project, and therefore they were able to work together, learn from each other, support each other, and deal with issues honestly since they were all in the same situation. The way it worked out, they needed to work with someone other than team members they ideally would have wanted to, and as a result, they found a way to work together to get the job done. Although they may not have been satisfied the day the teams were formed, the fact that they worked together as well as they did may have had an impact on the results of the survey, thus showing a higher level of satisfaction than a team that was made up of ideal partners. 


\section{Limitations and Future Research}

For convenience purposes, the survey was completed at a small liberal arts college with subjects in four different classes, all part of the business curriculum. The number of individuals that indicated they were able to pick their own team, but did not get to be part of their ideal group, was a very small population size. Only nine individuals indicated they did not get to be part of their ideal team, which is only $16.6 \%$ of the population answering the survey. Given the size of the sample population, no strong inference can be made with the limited data size. In order to determine if these results are able to be validated across other populations, a larger sample populations should be studied. This may include other classes and majors at the current college, or expanding the study to other colleges to determine if any anomalies existed within the current study.

\section{Conclusion}

Research has shown that students prefer to work on teams that have been self-chosen versus appointed. This would appear to especially be true for individuals that are part of the team they ideally wanted to be with. However, what impact on the learning environment takes place if students that are asked to self-choose a team and they do not end up being part of their ideal team. In four business classes at Wisconsin Lutheran College where approximately half the students were assigned to a team and the other half chose their own team, showed that the students that were assigned their team were more satisfied with the learning experience than those that chose their team, whether they were part of their ideal team or not. Although these results did not support the author's hypotheses, it may be an indication that factors other than how teams were chosen play a bigger role in the learning satisfaction. The author is convinced that a greater understanding of this issue must be gained, to insure the best learning environment for all students. If indeed little difference is seen between students' experiences when they are assigned teams or can choose their own partners, other factors can and should be considered to make that determination. As a result, further research on this issue is needed to confirm or refute the results of the study completed. It is too important to the students we serve, not to know. 


\section{References}

Amato, C. H., \& Amato, L. H. (2005). Enhancing student team effectiveness: Application of Myers-Briggs personality assessment in business courses. Journal of Marketing Education, 27(1), 41-51. http://dx.doi.org/10.1177/0273475304273350

Arrow, H., McGrath, J. E., \& Berdahl, J. L. (2000). Small groups as complex systems: Formation, coordination, development, and adaptation. Sage Publications.

Bosco, S. M., Jervis, K. J., \& Harvey, D. M. (2009). The Effect of Team Selection Method on the Occurrence and Nature of Conflict. Journal of Applied Research for Business Instruction, 7(1), n1.

Cozby, P. C., \& Bates, S. C. (2012). Methods in behavioral research. New York: McGraw-Hill.

Cutshall, R., Gavirneni, S., \& Schultz, K. (2007). Indiana University's Kelley School of Business uses integer programming to form equitable, cohesive student teams. Interfaces, 37(3), 265-276. http://dx.doi.org/10.1287/inte.1060.0248

Decker, W. H., Calo, T. J., Yao, H., \& Weer, C. H. (2015). Preference for group work in China and the US. Cross Cultural Management, 22(1), 90-115. http://dx.doi.org/10.1108/CCM-03-2013-0053

Djajadikerta, G. (2010). The Lesson Study Based Team Assignment Model for University Accounting and Business Students. The International Journal of Learning 17 (3) 179-188).

Hartig, V. (ed.) (1998), To God be the Glory - 25 years. Wisconsin Lutheran College Magazine - Special Anniversary Service booklet. pp. 2-21.

Hartig, V. (ed.) (2013), Celebrating 40 years of God's Grace. Wisconsin Lutheran College Magazine 25(2) pp. 20-21.

http://www.wlc.edu/WhoWeAre/

Jassawalla, A. R., Malshe, A., \& Sashittal, H. (2008). Student perceptions of social loafing in undergraduate business classroom teams. Decision Sciences Journal of Innovative Education, 6(2), 403-426. http://dx.doi.org/10.1111/j.1540-4609.2008.00183.x

Jones, G.R., \& George, J. M. (2013). Essentials of Contemporary Management. McGraw-Hill Irwin.

Loughry, M. L., Ohland, M. W., \& Woehr, D. J. (2014). Assessing teamwork skills for assurance of learning using CATME Team Tools. Journal of Marketing Education, 36(1), 5-19. http://dx.doi.org/10.1177/0273475313499023

Lüthje, C., \& Prügl, R. (2006). Preparing business students for co-operation in multi-disciplinary new venture teams: Empirical insights from a business-planning course. Technovation, 26(2), 211-219. http://dx.doi.org/10.1016/j.technovation.2004.10.010

Marks, M. B., \& O'Connor, A. H. (2013). Understanding students' attitudes about group work: What does this suggest for instructors of business? Journal of Education for Business, 88(3), 147-158. http://dx.doi.org/10.1080/08832323.2012.664579 
O'Neill, T. A., \& Kline, T. J. (2008). Personality as a predictor of teamwork: A business simulator study. North American Journal of Psychology, 10(1), 65.

Pragman, C. H., Bowyer, S. D., \& Flannery, B. L. (2010). Using student feedback to assess team projects in a required, cross-disciplinary, undergraduate management course. Academy of Educational Leadership Journal, 14(2), 85.

Stone, R. W., \& Bailey, J. J. (2007). Team conflict self-efficacy and outcome expectancy of business students. Journal of Education for Business, 82(5), 258-266. http://dx.doi.org/10.3200/JOEB.82.5.258-266

Sung Eun Chung, S., \& Meneely, J. (2012). Profiling Group Dynamics Within Business and Design Student Teams: Relationships Among Personality Traits, Problem-Solving Styles, and Creative Performance. Journal of Interior Design, 37(3), 23-45. http://dx.doi.org/10.1111/j.19391668.2012.01079.x

Winter, J., Neal, J. C., \& Waner, K. K. (2005). Student Teams Learning to Cope with Conflict. Delta Pi Epsilon Journal, 47(2), 67-74. 